\title{
sciendo
}

\section{POSTMORTEM DEGRADATION OF DESMIN AND DYSTROPHIN IN BREAST MUSCLES FROM CAPONS AND COCKERELS*}

\author{
Dorota Wojtysiak ${ }^{1}$, Jolanta Calik², Józefa Krawczyk², Joanna Wojciechowska-Puchałka \\ Joanna Obrzut ${ }^{2}$, Karolina Nahajło ${ }^{1}$
}

\author{
'Department of Animal Anatomy, Institute of Veterinary Sciences, University of Agriculture in Krakow, \\ Al. Mickiewicza 24/28, 30-059 Kraków, Poland \\ ${ }^{2}$ Department of Poultry Breeding, National Research Institute of Animal Production, \\ 32-083 Balice n. Kraków, Poland \\ •Corresponding author: wojtysiakd@wp.pl
}

\begin{abstract}
In recent years, consumers have increasingly sought niche food products with specific aroma and flavour, and rich in nutrients. With a growing demand for quality poultry products, there is an opportunity to increase production of capons, which are more and more often marketed as high quality products, because their meat is more delicate, tender and juicy. Therefore the objective of this study was to compare meat quality parameters and rate of protein degradation between capon and cockerel breast muscle during postmortem aging. Fibre type diameter, intact desmin and dystrophin contents at $15 \mathrm{~min}, 24 \mathrm{~h}$, and $48 \mathrm{~h}$ postmortem and the following technological parameters of breast meat were also determined: $\mathrm{pH}_{15}, \mathrm{pH}_{24}, \mathrm{pH}_{48}$, drip loss, shear force. The study was carried out on hybrids between Rhode Island Red cockerels (R-11) and Yellowleg Partridge hens ( $\dot{Z}-33)$ aged 24 weeks. The current findings indicate that compared with cockerel breast muscles, the capon breast muscles had significantly higher $\mathrm{pH}_{15}(\mathrm{P} \leq \mathbf{0 . 0 1})$, and lower drip loss $(\mathrm{P} \leq \mathbf{0 . 0 1})$ and shear force values $(\mathbf{P} \leq \mathbf{0 . 0 5})$. Additionally, the intensity of intact desmin and dystrophin in capon breast samples at $24 \mathrm{~h}$ and $48 \mathrm{~h}$ postmortem was significantly lower $(\mathrm{P} \leq 0.05)$ than that in the cockerel breast sample. In turn, the lower rate of desmin and dystrophin degradation $(\mathrm{P} \leq 0.05)$, along with higher drip loss in cockerel compared to capon breast muscles, may account for their lower muscle fibre diameters at $24 \mathrm{~h}$ and $48 \mathrm{~h}$ postmortem. Moreover, the rate of early postmortem $\mathrm{pH}$ decline can partly explain the variation of desmin and dystrophin degradation.
\end{abstract}

Key words: capon, meat quality, desmin, dystrophin

Muscles are an important part of the carcass composition and usually the main source of meat products for humans. In recent times, there has been an increase in the consumer demand for more variety and quality of poultry meat products, which

*This study was supported by DS-3253. 
has led to a reappraisal of the use of traditional practices such as caponization (Tor et al., 2002). Capons are male chickens surgically castrated before reaching sexual maturity and slaughtered at a minimum age of 140 days. Caponization influences not only secondary sexual characteristics, including degeneration of the comb and wattle, and behavioural changes (Chen et al., 2006), but also meat quality (Chen et al., 2007; Shao et al., 2009; Sinanoglou et al., 2011; Calik et al., 2015; Adamski et al., 2016; Gesek et al., 2017; Kwiecień et al., 2018). Tor et al. (2002, 2005) indicated that capons reach higher body weight, and their meat is more delicate and juicy. Chen et al. (2006) have shown that caponization enhances flavour, texture and meat juiciness when compared with intact cockerels. Many previous studies have shown that during the process of meat physico-chemical parameters formation, postmortem changes in muscle tissue determine the subsequent usefulness of meat for production and culinary purposes (Morrison et al., 1998; Melody et al., 2004; Zhang et al., 2006; Bee et al., 2007; Wojtysiak et al., 2008; Wojtysiak and Górska, 2018). The development of meat quality during aging is dependent on the postmortem loss of longitudinal and lateral integrity of the muscular tissue, as a result of proteolytic degradation of cytoskeletal proteins resulting in tenderization of meat (Young et al., 1980; Ouali, 1992; Hughes et al., 2014). Postmortem aging has been widely demonstrated to be essential for the desirable palatability characteristics of meat. Proteolysis of key myofibrillar proteins during aging plays a significant role in the determination of meat water holding capacity (Zhang et al., 2006; Bee et al., 2007; Wojtysiak and Połtowicz, 2015) and meat tenderness, which is considered by consumers to be one of the most important eating quality traits (Koohmaraie, 1994; Shackelford et al., 2001; Wojtysiak et al., 2008).

Cytoskeletal proteins (microtubules, microfilaments and intermediate filaments) of striated skeletal muscle fibres form a dense meshwork of fibrous structures, which constitute more than $85 \%$ of all cell proteins. Among the key myofibrillar proteins, desmin is essential for the maintenance of myofibrillar structure and functional integrity as it is a major subunit of the intermediate filaments in skeletal muscles (Taylor et al., 1995). Another important cytoskeletal protein is dystrophin, which stabilizes the plasma membrane of striated muscle cells (Minetti et al., 1992). In birds and, in particular, in chicken breast muscle, the role of postmortem proteolysis is poorly documented. No such data are available for capons.

Therefore, the aim of this study was to compare meat quality parameters and rate of protein degradation between capon and cockerel breast muscle during postmortem aging.

\section{Material and methods}

The experiment used hybrids between Rhode Island Red cockerels (R-11) and Yellowleg Partridge hens ( $\dot{Z}-33)$. A total of 80 cockerels were randomly assigned to two groups of 40 birds each. Group I (control) consisted of uncastrated cockerels, while birds from group II (experimental) were castrated. Castration was performed 
by a veterinarian under local anaesthesia at $8 \mathrm{wk}$ of age, and the experimental procedures were conducted with the approval of the Ethics Committee No. 1121 from 27 November 2014. Birds were kept under normal environmental conditions (temperature of $16-18^{\circ} \mathrm{C}$, relative humidity of $60-75 \%$ ) in the barn system at a stocking density of 7 birds $/ \mathrm{m}^{2}$. Throughout rearing and fattening, i.e. until 24 wk of age, birds were allowed free access to water and feed. A three-phase feeding regimen was used. Table 1 presents the results of nutrient analysis for the diets, which was performed in accordance with AOAC procedures. At 24 wk of age, 8 birds whose body weights were similar to the group average (i.e. $2560 \pm 55.13$ for cockerels and $2773 \pm 182.72$ for capons) were selected for slaughter. Cockerels and capons were subjected to 12 $\mathrm{h}$ of feed (but not water) withdrawal. The birds were slaughtered using standard killing methods by decapitation. After slaughter, the birds were checked for castration success (removal of the testes). Next, samples of breast muscle (Pectoralis major muscle) were excised from each carcass 15 min postmortem, and after $24 \mathrm{~h}$ and $48 \mathrm{~h}$ of refrigerated storage $\left(4^{\circ} \mathrm{C}\right)$ of muscle fragments to determine the microstructural parameters of the meat. For muscle acidity, $\mathrm{pH}_{15}$ and $\mathrm{pH}_{24}$ (after chilling) were measured on the pectoral muscle not cut from the carcass, whereas $\mathrm{pH}_{48}$ was measured on cut muscles, which was associated with the determination of parameters such as drip loss and shear force. Muscle $\mathrm{pH}$ was measured using a Cyber Scan $110 \mathrm{pH}$ meter (Eutech Instruments Pte Ltd/Oakton Instruments, Belgium) with a glass electrode standardized for $\mathrm{pH} 4.0$ and 7.0 according to Polish Standard PN-77/a-82058 with automatic correction for muscle temperature at $15 \mathrm{~min}, 24 \mathrm{~h}$, and $48 \mathrm{~h}$ postmortem. Drip loss was measured in duplicate samples. After thorough weighing ( $\mathrm{e}=0.001 \mathrm{~g}$ ), samples of about $50 \mathrm{~g}$ were placed in sealed containers. Drip loss was calculated $48 \mathrm{~h}$ postmortem as a percentage of muscle weight loss over 24-h storage of the meat at $4^{\circ} \mathrm{C}$. Meat samples for Warner-Bratzler shear force (WB) were taken after $24 \mathrm{~h}$ of cooling at $4^{\circ} \mathrm{C}$. Next, the chops were cooked in a water bath at $100^{\circ} \mathrm{C}$ until a core temperature of $78^{\circ} \mathrm{C}$ was obtained in the thickest part of the sample and then cooled. From the thickest upper part of cooked and chilled breast muscles, two cylindrical pieces $(1.27 \mathrm{~cm}$ in diameter) were cut for analysis of shear force. Shear force was determined based on measurement of the maximum force needed to shear the sample with a triangular Warner-Bratzler attachment. The cylindrical piece was cut at three points perpendicular to the orientation of the muscle fibres and the mean was calculated. This test was performed using an Instron 5542 machine (UK).

Table 1. Results of chemical analysis of the feed mixtures

\begin{tabular}{|c|c|c|c|}
\hline Item & $\begin{array}{l}\text { Mixture I: } \\
1-7 \text { weeks }\end{array}$ & $\begin{array}{l}\text { Mixture II: } \\
\text { 8-16 weeks }\end{array}$ & $\begin{array}{l}\text { Mixture III: } \\
\text { 17-24 week: }\end{array}$ \\
\hline Dry matter $(\%)$ & 88.38 & 87.86 & 88.54 \\
\hline Crude ash (\%) & 7.37 & 5.83 & 3.96 \\
\hline Crude protein $(\%)$ & 19.30 & 18.66 & 16.30 \\
\hline Crude fat (\%) & 2.23 & 2.02 & 2.29 \\
\hline Crude fibre (\%) & 2.34 & 2.54 & 2.38 \\
\hline $\begin{array}{r}\text { Metabolizable energy }(\mathrm{MJ} / \mathrm{kg}) \\
(\mathrm{kcal} / \mathrm{kg})\end{array}$ & $\begin{array}{l}11.92 \\
2850\end{array}$ & $\begin{array}{l}12.05 \\
2880\end{array}$ & $\begin{array}{l}12.18 \\
2910\end{array}$ \\
\hline
\end{tabular}


To determine muscle fibre size and for immunohistochemical analysis, the experiment used breast muscle fragments of cockerels and capons, collected from the left carcass side 15 min postmortem, and after 24 and $48 \mathrm{~h}$ of refrigerated storage $\left(4^{\circ} \mathrm{C}\right)$. Muscle samples were cut into $1 \mathrm{~cm}^{3}$ pieces (parallel to the muscle fibres) and frozen in isopentane that was cooled using liquid nitrogen and stored at $-80^{\circ} \mathrm{C}$ until subsequent analyses. Samples were mounted on a cryostat chuck with a few drops of tissue-freezing medium (Tissue-Tek; Sakura Finetek Europe, Zoeterwoude, The Netherlands). Transverse sections $\left(10-\mu \mathrm{m}\right.$ thick) were cut at $-20^{\circ} \mathrm{C}$ in a cryostat (Slee MEV, Germany). To determine desmin activity, frozen sections were stained as previously reported by Wojtysiak and Połtowicz (2015). Briefly, sections were fixed with $4 \%$ formaldehyde, as paraformaldehyde (PFA), in $0.1 \mathrm{M}$ phosphate buffer (PB) ( $\mathrm{pH}$ 7.4). Next, sections were incubated for $30 \mathrm{~min}$ in 5\% normal goat serum (NGS). They were then incubated overnight at $4{ }^{\circ} \mathrm{C}$ with primary monoclonal antibody (NCL-DES-DERII, Novocastra, Leica, UK) at 1:100 dilution. After several washes in $0.01 \mathrm{M}$ sodium phosphate buffer (PBS) containing $0.05 \%$ Triton-X, sections were incubated overnight at $4{ }^{\circ} \mathrm{C}$ with goat anti-mouse secondary antibodies conjugated to Alexa Fluor 555 (Molecular Probes) at 1:250 dilution. After final washing, preparations were mounted in Vectashield medium (Vector Labs, Burlingame, CA) and examined with a Zeiss Axio Vision A.2 fluorescence microscope. In controls, there was immunostaining observed when primary antisera were omitted. In turn, to determine dystrophin activity, frozen serial sections were fixed with $4 \%$ formaldehyde, as paraformaldehyde (PFA), in $0.1 \mathrm{M}$ phosphate buffer (PB) (pH 7.4), and next after several washes in $0.01 \mathrm{M}$ sodium phosphate buffer (PBS), preparations were incubated in $10 \% \mathrm{H}_{2} \mathrm{O}_{2}(10 \mathrm{~min})$ to neutralize endogenous peroxidase. In the next stage, after washing in $0.01 \mathrm{M}$ sodium phosphate buffer (PBS), preparations were incubated with a primary mouse monoclonal antibody against dystrophin (NCL-DYS3, Novocastra, Leica, dilution 1:20), at room temperature for $1 \mathrm{~h}$. The reaction was visualized by the NovoLink ${ }^{\mathrm{TM}}$ Polymer Detection System (Leica, Germany) according to the manufacturer's instruction. Finally, sections were dehydrated in a graded series of ethyl alcohol, cleared in xylene and mounted in DPX mounting medium (Fluka, Buchs, Switzerland). Sections were examined using a NIKON E600 light microscope. Muscle fibre diameters were estimated based on 100 randomly chosen fibres in each preparation and in all meat storage periods using computer-based image analysis system MultiScan v. 14.02 (Poland).

Intact desmin and dystrophin were analysed using Western immunoblotting according to Wojtysiak and Górska (2018). To this end, whole muscle extracts were obtained by homogenizing muscle samples with 10 volumes of ice cold extraction buffer ( $\mathrm{pH} 8.3$ ) containing $50 \mathrm{mM}$ Tris and $10 \mathrm{mM}$ EDTA. The muscle homogenate was diluted 1:1 with protein denaturing buffer (4\% SDS, 20\% glycerol, $125 \mathrm{mM}$ Tris, $\mathrm{pH}$ 6.8) and heated at $50^{\circ} \mathrm{C}$ for $20 \mathrm{~min}$. Samples were centrifuged at $16000 \times \mathrm{g}$ and protein concentration was determined using BCA assay (Sigma Chemical Co, St. Louis, USA). Desmin was separated by SDS-PAGE on 10\% separating acrylamide gel with 4\% stacking acrylamide gel. In turn, dystrophin was separated by SDS-PAGE on $8 \%$ separating acrylamide gel with $4 \%$ stacking acrylamide gel. Gels for desmin and dystrophin were loaded with $60 \mu \mathrm{g}$ of protein per lane. Relative mo- 
lecular weights were determined using PageRulerTM Plus Prestained Protein Ladder (Thermo Fisher Scientific, Inc. Waltham, MA, USA). Discontinuous gels were run at $100 \mathrm{~V}$ for $1.5 \mathrm{~h}$. Gel was transferred to Immobilon-P transfer membrane (Millipore) overnight at $4^{\circ} \mathrm{C}$ and $30 \mathrm{~mA}$ in buffer containing $25 \mathrm{mM}$ Tris, $193 \mathrm{mM}$ glycine, and $15 \%$ methanol. After blocking with $10 \%$ non-fat dried milk in Tris-buffered saline $\mathrm{pH} 7.4$ containing $0.05 \%$ Tween 20 for $1 \mathrm{~h}$, the membrane was incubated at room temperature with primary monoclonal antibodies: NCL-DES-DERII (Novocastra, Leica, UK, dilution 1:250) and NCL-DYS3 (Novocastra, Leica, dilution 1:20) for $2 \mathrm{~h}$ at room temperature. Membrane was washed three times ( $5 \mathrm{~min}$ ) with TBST after each incubation. Bound primary antibody was visualized with goat anti-mouse alkaline phosphatase conjugate (Pierce Chemical Co., USA) diluted 1:2500, followed by detection of alkaline phosphate activity with bromo-chloroindolyl phosphate and nitroblue tetrazolium. The immunoblots were electronically scanned and the intensity of intact desmin and dystrophin was calculated using densitometric method (ImageJ ver. 1.33U, National Institutes of Health, USA). Because the same amount of protein from each sample was loaded on SDS gels, relative abundance of intact desmin and dystrophin at 15 min postmortem (as a reference standard to normalize the band intensities) of the capon and cockerel samples was taken as $100 \%$ with respect to each muscle sample. The intact desmin and dystrophin contents at $24 \mathrm{~h}$ and $48 \mathrm{~h}$ postmortem were expressed as percentages of the $15 \mathrm{~min}$ postmortem samples. The obtained ratio was used for statistical analysis.

Differences among the capon and cockerel breast samples were analysed using one-way analysis of variance (General Linear Models procedure). A probability of $\mathrm{P} \leq 0.05$ was considered statistically significant. The data were expressed as least squares means (LSM) and standard deviation (SD).

\section{Results}

The results of analysis of muscle fibre size and physico-chemical parameters, including $\mathrm{pH}$, shear force and drip loss of breast muscles of capons and cockerels are presented in Table 2. In the case of acidity, breast muscles had significantly higher $\mathrm{pH}$ values measured 15 min postmortem in capons $(\mathrm{P} \leq 0.01)$ than in cockerels. For the other periods of refrigerated storage of meat, no significant differences in meat acidity were observed between the analysed groups $(\mathrm{P}>0.05)$. Moreover, the breast muscles from capons were characterized by significantly lower $(\mathrm{P} \leq 0.01)$ drip loss values compared to the breast muscles from cockerels. Analysis of the effect of caponizing procedure on Warner-Bratzler shear force showed that capons had more delicate meat, as evidenced by the significantly lower Warner-Bratzler shear force $(\mathrm{P} \leq 0.05)$ values compared to cockerels. Caponization also had a significant effect on muscle fibre size $24 \mathrm{~h}$ and $48 \mathrm{~h}$ postmortem, where significantly smaller muscle fibres $(\mathrm{P} \leq 0.05)$ were noted in breast muscles from cockerels compared with capons. Immediately after slaughter, at $15 \mathrm{~min}$, no such significant differences in muscle fibre size were observed between the animal groups under analysis. 
Table 2. Effect of caponization on muscle fibre diameter and physico-chemical parameters of breast muscle. Values are expressed as least squares means (LSM) and standard deviation (SD)

\begin{tabular}{l|c|c|c|c}
\hline \multirow{2}{*}{ Item } & \multicolumn{2}{c|}{ Cockerels } & \multicolumn{2}{c}{ Capons } \\
\cline { 2 - 5 } & LSM & SD & LSM & SD \\
\hline $\mathrm{pH}_{15}$ & $6.38 \mathrm{~A}$ & 0.66 & $6.65 \mathrm{~B}$ & 0.13 \\
$\mathrm{pH}_{24}$ & 5.89 & 0.15 & 5.99 & 0.07 \\
$\mathrm{pH}_{48}$ & 5.81 & 0.15 & 5.93 & 0.08 \\
Drip loss (\%) & $0.34 \mathrm{~A}$ & 0.05 & $0.24 \mathrm{~B}$ & 0.04 \\
Shear force (N) & $18.21 \mathrm{a}$ & 2.22 & $14.89 \mathrm{~b}$ & 2.02 \\
Muscle fibre diameters $(\mu \mathrm{m})$ & & & & \\
$\quad$ & 49.27 & 1.14 & 48.65 & 0.86 \\
15min & $45.73 \mathrm{a}$ & 1.08 & $48.38 \mathrm{~b}$ & 1,23 \\
$\quad 48 \mathrm{~h}$ & $45.48 \mathrm{a}$ & 0.92 & $47.93 \mathrm{~b}$ & 1,16 \\
\hline
\end{tabular}

$\mathrm{a}, \mathrm{b}$ - values in rows with different letters differ significantly $(\mathrm{P} \leq 0.05)$.

$\mathrm{A}, \mathrm{B}-$ as above for $\mathrm{P} \leq 0.01$.

The results of desmin localization and degradation in capon and cockerel breast meat during $48 \mathrm{~h}$ storage are presented in Figures 1 and 2. The Western-blot analysis showed that during the meat storage at $4{ }^{\circ} \mathrm{C}$ the level of intact desmin gradually decreased, and capon breast muscles were characterized by significantly lower $(\mathrm{P} \leq 0.05)$ levels of intact desmin measured $24 \mathrm{~h}$ and $48 \mathrm{~h}$ postmortem compared to cockerel meat. Furthermore, immunohistochemical analysis showed that in both capons and cockerels, desmin was not degraded evenly over the entire muscle fibre area. Desmin inside the muscle fibres degraded most rapidly. For desmin located at the periphery of the muscle fibres, i.e. at the sites of costameres, no degradation was observed even after $48 \mathrm{~h}$ refrigerated storage of the muscles.

The results of immunohistochemical analysis concerning the localization of dystrophin in the muscle fibres of capon and cockerel breast meat during $48 \mathrm{~h}$ refrigerated storage of the meat are presented in Figure 3. Microscope observations showed that dystrophin is localized in the muscle fibres on the inner cell membrane surface, and 15 min postmortem this protein was found in all the muscle fibres in both capons and cockerels. At $24 \mathrm{~h}$ postmortem, in both groups of animals, there were muscle fibres within which the analysed protein was not present, and the number of muscle fibres with loss of dystrophin was greater in capons. It is also worth noting that in both capons and cockerels, dystrophin was lost from the adjacent muscle fibres. During the next meat storage period, i.e $48 \mathrm{~h}$ postmortem, dystrophin degradation was found to progress in the muscle fibres, but the degradation of this protein was slowed in the breast muscles of cockerels compared to capons, in which only single muscle fibres with dystrophin were noted $48 \mathrm{~h}$ postmortem. These observations are also confirmed by the Western-blot analysis, which showed that dystrophin degradation during $48 \mathrm{~h}$ refrigerated storage of the meat did not occur evenly in both groups of animals (Figure 4). Accordingly, both $24 \mathrm{~h}$ and $48 \mathrm{~h}$ postmortem the intensity of intact dystrophin in cockerel breast muscles was significantly greater $(\mathrm{P} \leq 0.05)$ than that in capon breast muscles. 


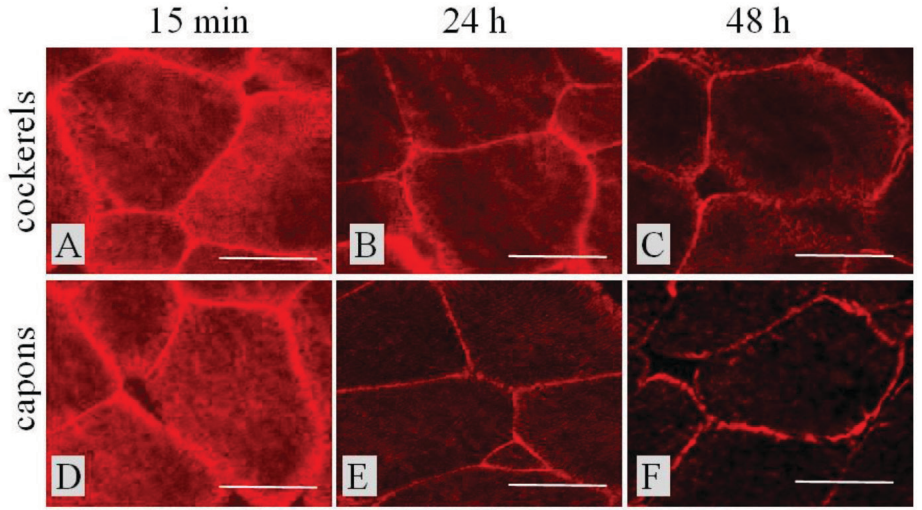

Figure 1. Exemplary cross-section of cockerels (A, B, C) and capons (D, E, F) breast muscles: immunohistochemical detection of desmin (NCL-DES-DERII). Samples were stored for $15 \min$ (A, D), $24 \mathrm{~h}$ $(\mathrm{B}, \mathrm{E})$, and $48 \mathrm{~h}(\mathrm{C}, \mathrm{D}) . \mathrm{Bar}=50 \mu \mathrm{m}$

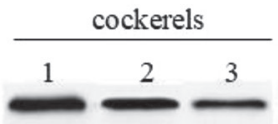

$100^{\mathrm{a}} \quad 78.5^{\mathrm{a}} \quad 32.2^{\mathrm{a}}$

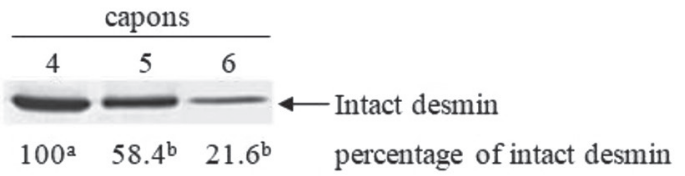

Least squares means (LSM) (between cockerels and capons breast muscles) with different letters differ significantly $(\mathrm{P} \leq 0.05)$.

Figure 2. Western blot analysis of desmin in cockerels and capons breast muscles. Samples were stored for $15 \mathrm{~min}$ (line 1, 4), $24 \mathrm{~h}$ (line 2, 5), and $48 \mathrm{~h}$ (line 3,6)

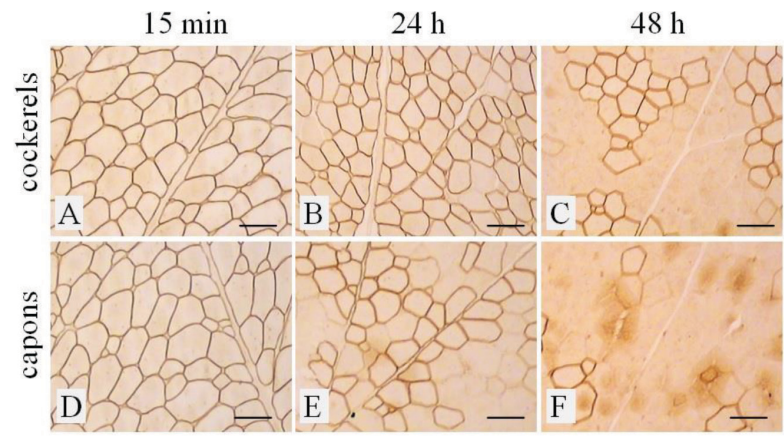

Figure 3. Exemplary cross-section of cockerels (A, B, C) and capons (D, E, F) breast muscle: immunohistochemical detection of dystrophin (NCL-DYS3). Samples were stored for $15 \mathrm{~min}$ (A, D), $24 \mathrm{~h}$ $(\mathrm{B}, \mathrm{E})$, and $48 \mathrm{~h}(\mathrm{C}, \mathrm{D}) . \mathrm{Bar}=50 \mu \mathrm{m}$ 


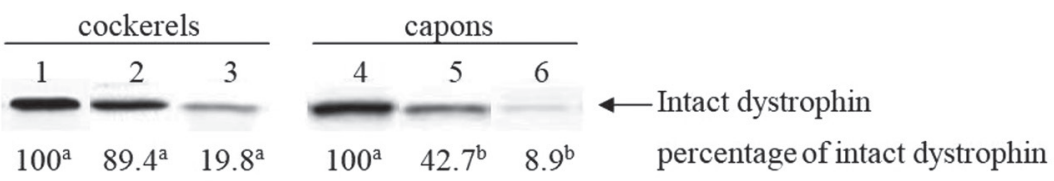

Least squares means (LSM) (between cockerels and capons breast muscles) with different letters differ significantly $(\mathrm{P} \leq 0.05)$.

Figure 4. Western blot analysis of dystrophin in cockerels and capons breast muscle. Samples were stored for $15 \mathrm{~min}$ (line 1, 4), $24 \mathrm{~h}$ (line 2, 5), and $48 \mathrm{~h}$ (line 3, 6)

\section{Discussion}

During the meat formation process, postmortem changes in muscle tissue determine the subsequent usefulness of meat for production and culinary purposes and they depend largely on the rate of cytoskeletal protein degradation. One of the major cytoskeletal proteins, intermediate filaments, which encircles the $\mathrm{Z}$ disks and radiates out to connect adjacent myofibrils, is desmin. Desmin is also one of the many proteins composing the cell membrane's skeleton, named costameres, and it is also considered to be the most important protein responsible for the lateral integrity of the muscle fibre. Huff-Lonergan et al. (2010) indicated that degradation of cytoskeletal protein is a natural process that occurs during postmortem conversion of muscle into meat and continues during storage.

In the present study, analysis of the rate of postmortem desmin degradation in the capon and cockerel breast muscles showed that during meat storage at $4{ }^{\circ} \mathrm{C}$, the level of desmin gradually declines, but this process is more rapid in the capon breast muscles, as evidenced by the lower content of intact desmin in muscle fibres at 24 and $48 \mathrm{~h}$ postmortem compared to the cockerel breast muscles. Likewise, for the other analysed protein, which is an important component of costameres, namely dystrophin, our study demonstrated a significant effect of caponization on increasing the rate of dystrophin degradation in the breast muscle fibres of capons compared to cockerels. In muscle fibres, dystrophin binds to the glycoprotein complex to form an important structural element of the muscle fibres, which couples the sarcolemma with actin filaments, forms connections between the sarcoplasmic cytoskeleton and extracellular matrix, and helps to maintain cell homeostasis (Minetti et al., 1992). Therefore, changes in the rate of postmortem protein degradation will not only affect muscle fibre structure, but they will also translate into the physico-chemical parameters of the meat. Bee et al. (2007) suggested that the rate of cytoskeletal protein degradation is significantly influenced by the rate of early $\mathrm{pH}$ decline. In their study with pigs, the authors showed that longissimus muscles with higher $\mathrm{pH}$ values at 45 min postmortem, compared to the muscles with significantly lower $\mathrm{pH}$ at $45 \mathrm{~min}$, with no differences in muscle acidity at $24 \mathrm{~h}$ postmortem, were characterized by a lower level of intact desmin $24 \mathrm{~h}$ and $48 \mathrm{~h}$ postmortem. These observations 
may explain the higher rate of postmortem desmin and dystrophin degradation in capon breast muscles, which were also characterized in our study by a more rapid $\mathrm{pH}$ decrease during the first $24 \mathrm{~h}$ postmortem (higher $\mathrm{pH}_{15}$ values and also no differences in meat acidity at $24 \mathrm{~h}$ postmortem). Koohmaraie (1992) indicated that in postmortem proteolysis a key role is played by the calpain protease system. There are two ubiquitous calpains, $\mu$ - and $\mu / \mathrm{m}$-calpain, that are present in avian skeletal muscle fibres (Sorimachi et al., 1995). It was reported that both calpains were activated and autolysed in postmortem chicken muscles (Chang and Chou, 2010), and Chang and Chou (2012) suggested that $\mu$-calpain, rather than $\mu / \mathrm{m}$-calpain, activity was correlated with postmortem degradation of cytoskeletal protein like desmin in duck muscle. Lee et al. (2008) found that $\mu$-calpain might be mobilized soon after slaughter, whereas at longer postmortem times $\mu / \mathrm{m}$-calpain and its autolyzed form were identified as the dominant calpain within the broiler meat (Soglia et al., 2018). Maddock et al. (2005) indicated that $\mu$-calpain autolysis is regulated by intracellular calcium, calpastatin, $\mathrm{pH}$, and ionic strength. The autolysis of $\mu$-calpain is a multistep process changing from $80 \mathrm{kDa}$ calpain to $76 \mathrm{kDa}$ via an intermediate $78 \mathrm{kDa}$ (Johnson and Guttmann, 1997). Autolysis of calpain is considered to be a hallmark for activation of calpain in postmortem muscle. It is therefore suggested that a greater proportion of the calpain catalytic subunit present as the $76 \mathrm{kDa}$ autolysis product indicates that a greater proportion of calpain has been active. Bee et al. (2007) demonstrated that compared to the muscles with a low rate of $\mathrm{pH}$ decrease postmortem, the muscles with a higher rate of $\mathrm{pH}$ decline had greater intensity of autolyzed $76 \mathrm{kDa}$ product and lower intensity of intact $80 \mathrm{kDa}$ calpain. This may indicate that calpain is more activated in muscles with faster $\mathrm{pH}$ decline, which may be one of the reasons for the higher rate of desmin and dystrophin degradation found in our study in the breast muscles of capons compared to cockerels.

As indicated by earlier studies, differences in the rate of desmin and dystrophin degradation also play an important role in determining tenderness and drip loss of meat during postmortem storage (Taylor et al., 1995; Zhang et al., 2006; Wojtysiak et al., 2008).

Studies with pigs (Zhang et al., 2006; Bee et al., 2007), chicken (Wojtysiak et al., 2008), and turkey (Wojtysiak and Górska, 2018) showed that high levels of desmin and dystrophin degradation determine less drip loss during postmortem aging. In turn, the slower rate of desmin degradation has been proposed to result in the shrinkage of muscle cells to form gaps between muscle cells and muscle bundles which thus translate as a high drip loss during postmortem aging (Offer and Cousins, 1992; Taylor et al., 1995; Huff-Lonergan and Lonergan, 2005). Huff-Lonergan et al. (2002) report that the extent of drip loss is also influenced by antemortem traits such as $\mathrm{pH}$ and temperature. The same authors consider that an important contribution to the level of drip loss postmortem is also made by the intracellular structures termed costameres, of which the proteins discussed in our study, namely desmin and dystrophin, are an important element. Costameres provide the structural framework responsible for attaching the myofibrils to the sarcolemma. It is the degradation of costamere proteins, and also the degradation of the integrin membrane protein which contribute to the opening of drip channels, thus determining the extent of drip loss. If 
costameric linkages remain intact during the conversion of muscle into meat, shrinkage of the myofibrils as the muscle goes into rigor would be transmitted to the entire cell via these proteinaceous linkages and would ultimately reduce volume of the muscle fibre itself (Kristensen and Purslow, 2001; Melody et al., 2004). Thus, the rigor process could result in mobilization of water not only out of the myofibril, but also out of the extramyofibril spaces as the overall volume of the cell is constricted (Huff-Lonergan and Lonergan, 2005), and this may explain not only the higher drip loss in cockerel breast samples found in our study, where both desmin and dystrophin degraded more slowly compared to capon breast samples, but also the smaller muscle fibres observed at $24 \mathrm{~h}$ and $48 \mathrm{~h}$ in the cockerel breast muscles. It is notable that similar to the earlier studies with pigs (Wojtysiak and Połtowicz, 2015) and turkeys (Wojtysiak and Górska, 2018), the immunohistochemical reaction analysed under a confocal scanning microscope in our study showed that desmin degradation in the muscle fibres is also dependent on its localization. Thus, the earliest signs of desmin degradation, in both capons and cockerels, were observed within the muscle fibres, where desmin encircles the $\mathrm{Z}$ line and radiates out to connect adjacent myofibrils. The slowest degradation occurred for desmin localized at the periphery of the muscle fibres. Degradation of the $\mathrm{Z}$ line, as noted before in this discussion, is influenced mainly by the calpain system, These enzymes cause the fragmentation of myofibrils, i.e. degrade proteins such as desmin (Dolatowski et al., 2004), troponin T and I (Offer and Cousins, 1992), tropomyosin, protein C, vinculin, titin, and nebulin (Goll et al., 1990; Koohmaraie, 1994), which is one of the important elements of meat tenderization. Therefore, the faster rate of desmin degradation observed in our study in the breast muscle fibres of capons may partly explain the lower shear force values obtained for the breast muscles of capons compared to cockerels. Similarly, Melody et al. (2004) and Wojtysiak et al. (2008) also pointed to a significant relationship between the level of intact desmin and meat tenderness. Evidence to the contrary was provided by Therkildsen et al. (2002), who found no significant relationships between the rate of desmin degradation and meat tenderness. It is worth noting that the presence or absence of significant correlations between meat tenderness and the level of intact desmin is probably associated not only with the rate of the degradation of muscle proteins, but also with many other factors such as collagen content, sarcomere length and, most importantly, intramuscular fat content. Earlier studies with capons have shown that the main effect of the caponization is the increasing of the overall fatness in different parts such as abdominal, subcutaneous and intramuscular (Tor et al., 2005; Calik et al., 2015; Franco et al., 2016; Gesek et al., 2017). Thus, the lower shear force values obtained in our study for capon breast muscles may also be associated with the intramuscular fat content.

In summary, we conclude that high levels of desmin and dystrophin degradation were probably associated with low drip loss and shear force values in capon breast muscles. On the other hand, compared with capon breast muscles, the lower rate of desmin and dystrophin degradation, coupled with a higher drip loss of cockerel breast muscles may explain their lower muscle fibre diameters at $24 \mathrm{~h}$ and $48 \mathrm{~h}$ postmortem. Moreover, our results indicate the rate of early postmortem $\mathrm{pH}$ decline can partly explain the variation of desmin and dystrophin degradation. 


\section{References}

A d a m ski M., Kuźni a c ka J., B an a s zak M., We gner M. (2016). The analysis of meat traits of Sussex cockerels and capons (S11) at different ages. Poultry Sci., 95: 125-132.

B e e G., Anderson A.L., L on ergan S.M., Huff-Lonergan E. (2007). Rate and extent of $\mathrm{pH}$ decline affect proteolysis of cytoskeletal proteins and water-holding capacity in pork. Meat Sci., 76: 359-365.

Calik J., Połtowicz K., Świątkiewicz S., Krawczyk J., Nowak J. (2015). Effect of caponization on meat quality of Greenleg Partridge cockerels. Ann. Anim. Sci., 15: 541-553.

Chang Y.-S., Chou R.-G.R. (2010). Postmortem degradation of desmin and calpain in breast and leg and thigh muscles from Taiwan black-feathered country chickens. J. Sci. Food Agric., 90: 2664-2668.

Chang Y.-S., Chou R.-G.R. (2012). Postmortem role of calpains in Pekin duck skeletal muscles. J. Sci. Food Agric., 92: 1620-1626.

Chen K.L., H sieh T.Y., Chiou P.W.S. (2006). Caponization effects on growth performance and lipid metabolism in Taiwan country chicken cockerels. Asian-Austral. J. Anim. Sci., 19: $438-443$.

Chen K.L. Chen T.T., L in K.J., C h i o u P.W.S. (2007). The effect of caponization age on muscle characteristics in male chicken. Asian-Austral. J. Anim. Sci., 20: 1684-1688.

D o lat ow ski Z. J., Tw a d a J., D u dek M. (2004). Changes in hydration of meat during the ageing process (in Polish). Annales UMCS, 59: 1595-1606.

Fran c o D., P a te ir o M., R o is D., V á z que z J.A., L o r e n z o J.M. (2016). Effects of caponization on growth performance, carcass and meat quality of Mos breed capons reared in free-range production system. Ann. Anim. Sci., 16: 909-929.

G e s e k M., Z aw a d zk a M., M u raw s k a D. (2017). Effects of caponization and age on the histology, lipid localization, and fiber diameter in muscles from Greenleg Partridge cockerels. Poultry Sci., 96: 1759-1766.

Gol1 D.E., Kle es e W.C., Okitani A., Kumamoto T., Cong J., Kapprel1 H-P. (1990). Historical background and current status of the $\mathrm{Ca}^{2+}$-dependent proteinase system. In: Intracellular Calcium-Dependent Proteolysis, Mellgren R.L. Murachi T. (eds). Boca Raton, FL: CRC, pp. 3-24.

Huff-L on ergan E., L on ergan S.M. (2005). Mechanisms of water-holding capacity of meat: The role of postmortem biochemical and structural changes. Meat Sci., 71: 194-204.

Huff - L o nergan E., B a a s T.J., M l e k M., D e k ker s J.C.M., Prus a K., R o th s child M.F. (2002). Correlations among selected pork quality traits. J. Anim. Sci., 80: 2-10.

Huff-L onergan E., Zhang W., L onergan S.M. (2010). Biochemistry of postmortem muscle - lessons on mechanisms of meat tenderization. Meat Sci., 86: 184-195.

Hughes J.M., O is e th S.K., Purs low P.P., Warner R.D. (2014). A structural approach to understanding the interactions between colour, water-holding capacity and tenderness. Meat Sci., 98: $520-532$.

J ohn s o n G.V., Guttm a n n R.P. (1997). Calpains: intact and active? Bioessays, 19: 1011-1018.

K o o h m a r a i e M. (1992). Effect of pH, temperature, and inhibitors on autolysis and catalytic activity of bovine skeletal muscle $\mu$-calpain. J. Anim. Sci., 70: 3071-3080.

K o o h m ar a i e M. (1994). Muscle proteinases and meat aging. Meat Sci., 36: 93-104.

Kristen se n L., Purs low P.P. (2001). The effect of ageing on water holding capacity of pork: the role of cytoskeletal proteins. Meat Sci., 58: 17-23.

Kwiecień M., Kasperek K., Tomaszewska E., Muszyński S., Jeżewska-| - Witk ow ska G., Wini arska - M i e c zan A., Grela E.R., Ka mińs k a E. (2018). Effect of breed and caponisation on the growth performance, carcass composition, and fatty acid profile in the muscles of Greenleg Partridge and Polbar breeds. Braz. J. Poultry Sci., 20: 583-594.

Le e H.L., S an té - L houtelli er V., Vigouroux S., Briand Y., Briand M. (2008). Role of calpains in postmortem proteolysis in chicken muscle. Poultry Sci., 87: 2126-2132.

M a d d o c k K.R., H u ff - L o n ergan E.J., R ow e L.J., L o n e rgan S.M. (2005). Effect of pH and ionic strength on $\mu$ - and m-calpain inhibition by calpastatin. J. Anim. Sci., 83: 1370-1376.

Melody J.L., Lonergan S.M., Rowe L.J., Huiatt T.W., Mayes M.S., Huff-Loner- 
g a n E. (2004). Early postmortem biochemical factors influence tenderness and water-holding capacity of three porcine muscles. J. Anim. Sci., 82: 1195-1205.

Minetti C., Beltrame F., Marcenaro G., Bonilla E. (1992). Dystrophin at the plasma membrane of human muscle fibers shows a costameric localization. J. Clin. Neuromuscul. Dis., 2: 99-109.

M or r is on H.E., M i e l c h e M.M., P u rl s ow P.P. (1998). Immunolocalisation of intermediate filament proteins in porcine meat. Fibre type and muscle-specific variations during conditioning. Meat Sci., 50: 91-104.

O ffer G., C o u s in s T. (1992). The mechanism of drip production: formation of two compartments of extracellular space in muscle post mortem. J. Sci. Food Agr., 58: 107-116.

O u a li A. (1992). Proteolytic and physicochemical mechanisms involved in meat texture development. Biochimie, 74: 251-265.

Sha ck elford S.D., Wh e e le r T.L., M e a d e M.K., R e a ga n J.O., B yrne s B.L., K o o h m a r a i e M. (2001). Consumer impressions of tender select beef. J. Anim Sci., 79: 2605-2614.

Sh a o Y., Wu C., Li J., Zh a o C. (2009). The effect of different caponization age on growth performance and blood parameters in male Tibetan chicken. Asian J. Anim. Sci., 4: 228-236.

Sinanoglou V.J., Mantis F., Miniadis-Meimaroglous S., Symeon G.K., Bize1 is I.A. (2011). Effects of caponisation on lipid and fatty acid composition of intramuscular and abdominal fat of medium-growth broilers. Br. Poultry Sci., 52: 310-317.

Soglia F., Zeng Z., Ga o J., Cavani C., Petracci M., Ertbjerg P. (2018). Evolution of proteolytic indicators during storage of broiler wooden breast meat. Poultry Sci., 97: 1448-1455.

Sorimachi H., Tsukahara T., Okada-Ban M., Sugita H., Ishiura S., Suzuki K. (1995). Identification of third ubiquitous calpain species - chicken muscle expresses four distinct calpains. Biochim. Biophys. Acta, 1261: 381-393.

Tay lor R.G., G e e s ink G.H., Thom p s on V.F., K o oh marai e M., Goll D.E. (1995). Is Zdisk degradation responsible for postmortem tenderization? J. Anim. Sci., 73: 1351-1367.

Therkildsen M., Melchior Larsen L., Bang H.G., Vestergaard M. (2002). Effect of growth rate on tenderness development and final tenderness of meat from Friesian calves. J. Anim. Sci., 74: 253-264.

Tor M., Estany J., Villalba D., Molina E., Cubilò M.D. (2002). Comparison of carcass composition by parts and tissues between cocks and capons. Anim. Res., 51: 421-443.

Tor M., Estany J., Frances ch D.A., Cubilò M.D. (2005). Comparison of fatty acid profiles of edible meat, adipose tissues and muscles between cocks and capons. Anim. Res., 54: 413-424.

Wojtys i a k D., Gó rs ka M. (2018). Effect of aging time on meat quality and rate of desmin and dystrophin degradation of pale, soft, exudative (PSE) and normal turkey breast muscle. Folia Biol. (Krakow), 66: 63-72.

Wojtysiak D., Połtowicz K. (2015). Effect of ageing time on microstructure, rate of desmin degradation and meat quality of pig longissimus lumborum and adductor muscles. Folia Biol. (Krakow), 63: 151-158.

Woj ty siak D., P ołt ow i c z K., K a ra sińs ki J. (2008). Relationship between post mortem desmin degradation and meat quality of poultry breast muscle. Med. Weter., 64: 1003-1006.

Young O.A., Gra a fhu is A.E., D a v e y C.L. (1980). Post-mortem changes in cytoskeletal proteins of muscle. Meat Sci., 5: 41-55.

Zhang W.G., L on ergan S.M., Gardner M.A., Huff-L on ergan E. (2006). Contribution of postmortem changes of integrin, desmin and $\mu$-calpain to variation in water holding capacity of pork. Meat Sci., 74: 578-585.

Received: 27 XII 2018

Accepted: 10 V 2019 